\title{
Variations in biochemical composition of juvenile Ruditapes philippinarum infected by a Vibrio sp.
}

\author{
S. Plana*, G. Sinquin, P. Maes, C. Paillard, M. Le Pennec \\ URA-CNRS 1513, Laboratoire de Biologie Marine, Faculté des Sciences, 6 Av. Le Gorgeu, F-29287 Brest Cédex, France
}

\begin{abstract}
The biochemical composition of young Ruditapes philippinarum was examined in 2 groups of clams, healthy clams and those experimentally infected with the pathogenic Vibrio P1 bacterium, to document utilization of biochemical reserves in individuals affected by 'brown ring disease'. After 1 mo of starvation, refeeding half of the experimental clams induced recovery as determined by the absence of visual signs of disease. Disease was associated with decreased dry weights in both fed and starved individuals (from 41 down to $30-35 \mathrm{mg} \mathrm{clam}^{-1}$ ). Glycogen was found to be the main biochemical reserve used by diseased individuals. A significant decrease in glycogen (from 45 down to 20-25 $\mathrm{mg} \mathrm{g}^{-1}$ dry wt) was observed in infected clams. Lipid and protein amounts were related to nutrjtional conditions. In refed individuals, carbohydrate reserves were low in spite of some recovery. These results could indicate an irreversible change of the digestive gland manifested by the inability to store reserves and distribute them to other tissues. In the field, mass mortalities observed in infected populations could result from the degeneration of metabolic activity.
\end{abstract}

KEY WORDS: Brown ring disease Clam - Vibrio B Blochemıcal reserves

\section{INTRODUCTION}

In 1980, a new venerid culture was developed along the French Atlantic Coast with the introduction of the Japanese clam Ruditapes philippinarum (Goulletquer et al. 1986). High mortalities associated with decreased dry weights and loss of metabolic reserves were first observed at the end of winter 1984 (Flassch 1987, Goulletquer 1989), but from 1987 to 1993, mass mortalities occurred in summer. Most dead clams exhibited a brownish deposit on the inner surface of the valves called 'brown ring' (Goulletquer 1988, Paillard et al. 1989). The disease, caused by a pathogenic Vibrio bacterium strain P1 (Paillard \& Mae 1990), has decimated populations of cultivated Japanese clams. Comparative studies of the digestive diverticula from healthy and infected clams using image analysis techniques have provided a quantitative evaluation of disease progression in which degeneration of digestive diverticula and alteration of the digestive cycle in infected indi-

•E-mail: plana@unjv-brest.fr viduals occurs (Plana \& Le Pennec 1991, Plana 1995). It was subsequently of interest to study how the disease disrupts the normal energy storage cycle by measuring levels of clam biochemical components. Two stress factors were tested, starvation and disease. Refeeding was used to study eventual recovery of clams.

\section{MATERIAL AND METHODS}

Rearing conditions. Healthy young Ruditapes philippinarum of uniform size (14 $\pm 1 \mathrm{~mm}$ long) were received from a nursery at Arcachon (France). 'Brown ring disease' was experimentally induced in individual clams by injection of $10^{7}$ cells of Vibrio P1 as described by Paillard \& Maes (1990). Individuals were separated into 2 groups: positive controls injected with sterile sea water and experimentally infected clams (500 individuals per group). Sea water was renewed every $3 d$ and water characteristics were determined daily in each tank. One month after injection, half of the control and half of the infected clams were fed with $40 \times$ $10^{6}$ cells Dunaliella primolecta $\mathrm{l}^{-1}$ every $2 \mathrm{~d}$. 
Specimen preparation. Infected clams were subdivided into different test groups (Stages 1 to 4 ) once the macroscopic signs of 'brown ring' disease were visible on the shells. Thirly individuals were sampled from the control and each test group of infected clams every $10 \mathrm{~d}$ during a $50 \mathrm{~d}$ period. Soft tissues were removed from the shells, washed with distilled water and weighed. Dry weights were determined after freeze drying and tissues were stored at $-30^{\circ} \mathrm{C}$. Clam viscera were pooled, in triplicate samples, to ensure sufficient biomass for biochemical analysis.

Biochemical analysis. Total lipids of the freeze-dried viscera were determined using a modification of the sulphuric acid-charring method described by Marsh \& Weinstein (1966) using tripalmitin as the standard. Polar lipids, which are stable, were precipitated by treatment of the mixture containing total lipids with activated silicic acid (Holland \& Gabbott 1971). After centrifugation [3000 rpm $(800 \times g), 10 \mathrm{~min})]$ the supernate was dried and anaiyzed by the modified sulphuric acid-charring method to determine the neutral-lipid content (Holland \& Hannant 1973). Total carbohydrates were measured as described by Dubois et al. (1956) using D-glucose as the standard. Glycogen was precipitated from the supernatant liquid with 100\% alcohol and released from the residue with boiling water. Absorbancies were measured after treatment as described by Dubois et al. (1956). Proteins were treated as described by Lowry et al. (1951) using bovine serum albumin as the standard.

All final analyses were performed in triplicate in all groups (which were pooled in triplicate) and expressed as $\mathrm{mg} \mathrm{g}^{-1}$ dry wt. Total organic matter was defined as the sum of gross biochemical components and expressed as $m g \mathrm{~g}^{-1}$ of dry wt. Dry weights, water content and C/P ratios (total carbohydrates/proteins) were calculated. First, the impact of disease on the evolution of each biochemical component during the starvation period and potential differences between the control and infected groups were tested with the Wilcoxon rank test at a confidence level of $95 \%$ (Sokal \& Rohlf 1985). We also analysed the incidence of refeeding in each group and between each group with the Mann-Whitney nonapparied test. In a second analysis, we tested the impact of each phase of the disease (in the infected group only) in starved and refed clams with the Mann-Whitney test at a confidence level of $95 \%$ (Sokal \& Rohlf 1985)

\section{RESULTS}

\section{Development of 'brown ring' disease}

In the infected group, the first macroscopic signs (Stage 1) were visible $10 \mathrm{~d}$ after infection: brown 'spots' and marks appeared on the inner surface of the valves in the 30 clams sampled. After $20 \mathrm{~d}$ (T20), some clams showed more serious lesions termed 'brown layers' (Stage 2) due to the accumulation of 'spots'; a portion of the individuals remained in 'Stage 1' (30 clams by stage were sampled). One month after bacterial injection (T30), the 'brown ring' was formed and masked the shell nacre (Stage 3). Half of the diseased clams were starved beyond T30 and, at T50, 45\% were dead and others showed 'Stage 3' signs. The other half of the diseased clams were fed after T30 and they secreted a layer of calcium that covered the 'brown ring'. By T50, no signs of 'brown ring' were visible (Stage 4 ) and $14 \%$ of the individuals had died. The only difference between control and recovered infected clams was that the valves were thicker in the latter specimens. No signs or mortality were noted in controls during the experiment (Stage 0).

\section{Biochemical analysis: impact of starvation}

Dry weights. In control clams, mean dry weights ranged from 45 to $40 \mathrm{mg}$ (Fig. 1). Inversely, a significant decrease to $30 \mathrm{mg}$ occurred in infected individuals (Fig. 1). Analysis of data indicated that dry weights were lower in infected clams from T10 (Wilcoxon's test: $\mathrm{p}=0.0309712$ ).

Water content. The soft tissue water content did not vary in both control and infected clams $(p=0.177529)$; data ranged from 82 to $85 \%$ (Fig. 2).

Total organic matter (sum of proteins, lipids and carbohydrates). In control and infected clams, organic content decreased slightly from 660 to $610 \mathrm{mg} \mathrm{g}^{-1}$ dry wt (Fig. 3). There was no difference between the 2 groups ( $\mathrm{p}=0.787402)$.

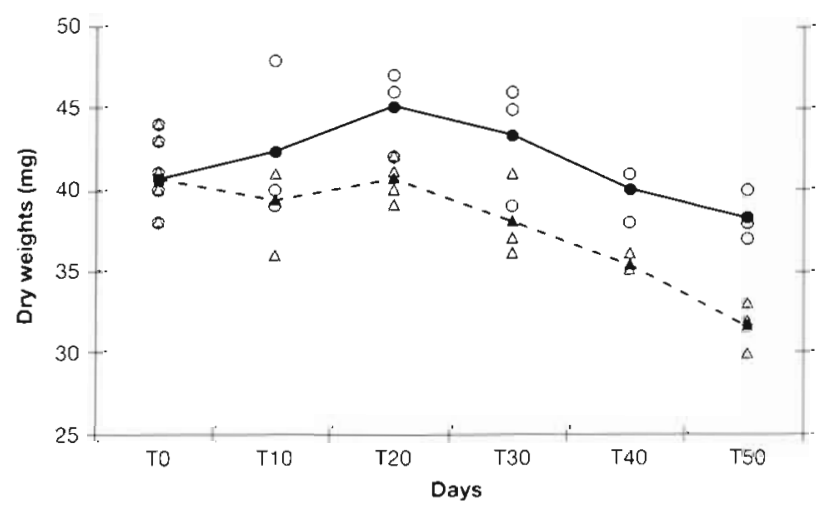

Fig. 1 Ruditapes philippinarum. Mean dry welghts (mg) in control $(0)$ and infected $(\Delta)$ Japanese clams maintained under starvation conditions. Solid symbols: means 


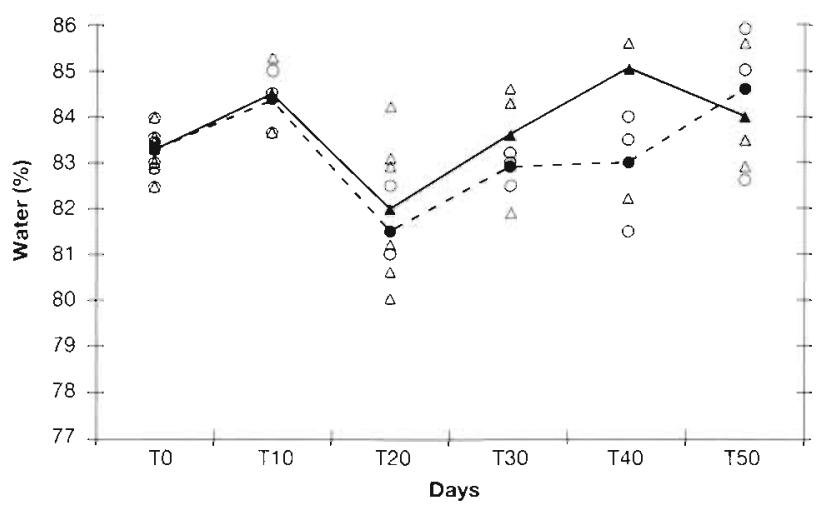

Fig. 2. Ruditapes philippinarum. Mean water contents (\%) in control $(O)$ and infected $(\Delta)$ Japanese clams maintained under starvation conditions. solid symbols: means

Proteins. Proteins were the major biochemical component ( 86 to $92 \%$ ), and, as for total organic matter, protein amounts decreased from 580 to $530 \mathrm{mg} \mathrm{g}^{-1}$ dry $w t$ in both control and infected clams during the experiment (Fig. 4); no significant difference between the 2 groups was noted ( $p=0.589636$ ).

Total lipids. Starved control individuals possessed highly variable lipid amounts but, as in infected clams, final data (from 25 to $27 \mathrm{mg} \mathrm{g}^{-1}$ dry wt) were approximately similar to first data (Fig. 5). Analysis of data showed no difference between the 2 groups ( $\mathrm{p}=$ 0.787402 ).

Neutral lipids. Amounts of neutral lipids showed the same pattern of distribution as total lipids. Data ranged from 15 to $20 \mathrm{mg} \mathrm{g}^{-1}$ dry wt. No difference was noted between control and infected clams ( $p=0.280712$ )

Total carbohydrates. In the control group, the lowest carbohydrate value was found at T10 (35 $\left.\mathrm{mg} \mathrm{g}^{-1}\right)$ but final data were at least $50 \mathrm{mg} \mathrm{g}^{-1}$ dry wt (Fig, 6). In infected clams, total carbohydrate amounts declined from 60 (T0) to $45 \mathrm{mg} \mathrm{g}^{-1}$ dry wt at T10 (Fig. 6). At T20,

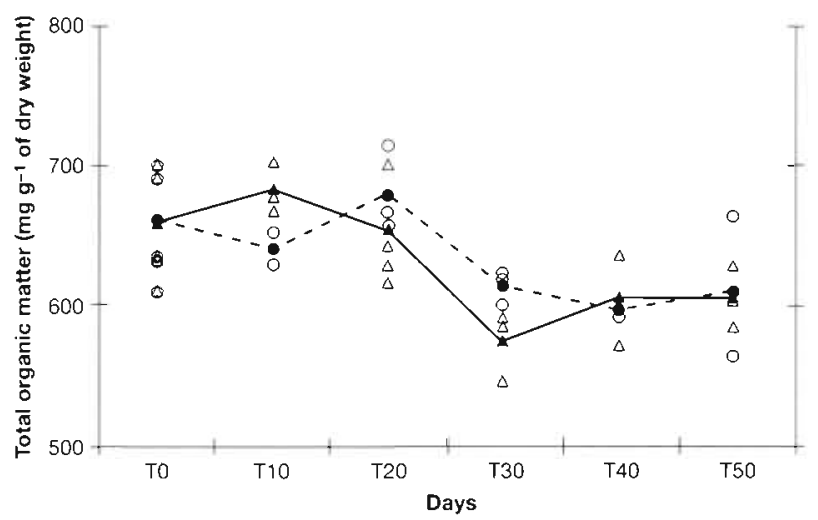

Fig. 3. Ruditapes philippinarum. Mean total organic matter amounts in control $(0)$ and infected $(\Delta)$ Japanese clams maintained under starvation conditions. Solid symbols: means

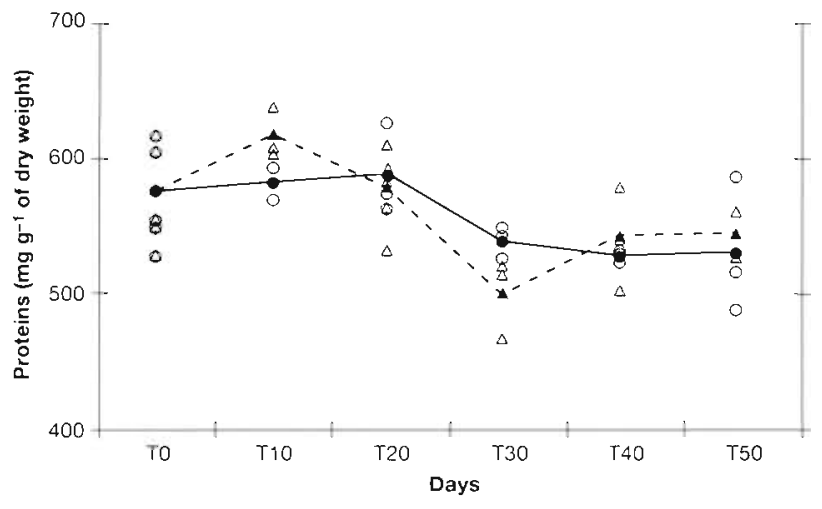

Fig. 4. Ruditapes philippinarum. Mean protein amounts in control (O) and infected ( $\Delta$ ) Japanese clams maintained under starvation conditions. Solid symbols: means

2 groups of individuals were distinguished: one in 'Stage 1' (Spots) and the other in 'Stage 2' (Layers). A marked decrease was observed in 'Stage 2 ' individuals, while 'Stage 1' clams had T20 values similar to those of the controls. Final data ranged from 34 to $36 \mathrm{mg} \mathrm{g}^{-1}$. The difference between control and infected clams was not significant ( $p=0.0590579$ ).

Glycogen. The amounts of glycogen present showed the same variations as for total carbohydrates in control and infected clams (Fig. 7). The same differentiation between 'Stage 1' and 'Stage 2' at T20 was necessary in the infected group and no difference was found between control and infected clams ( $p=0.105645)$.

\section{Biochemical analysis: impact of refeeding}

Dry weights. After T30, refeeding induced a decrease in dry weight in control and infected individuals (Fig. 8). Dry weights were lower in infected clams at T50 (35 mg) but the differences compared to

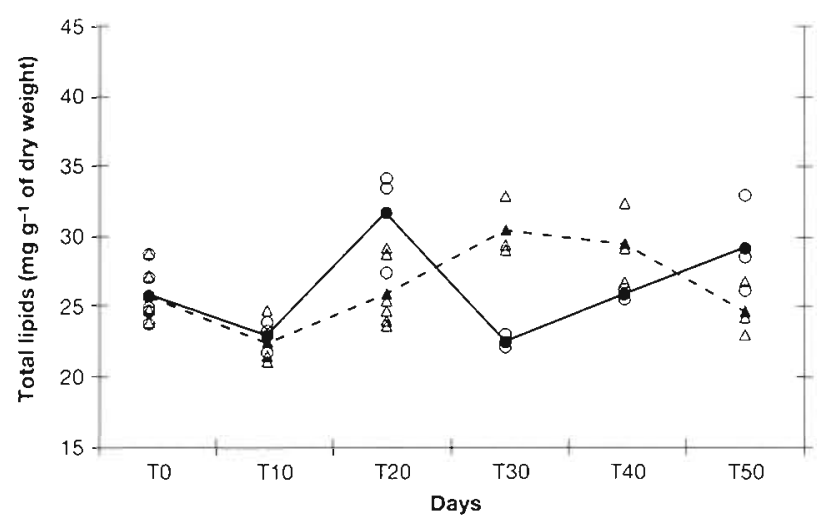

Fig. 5. Ruditapes philippinarum. Mean total lipid amounts in control $(0)$ and infected $(\Delta)$ Japanese clams maintained under starvation conditions. Solid symbols: means 


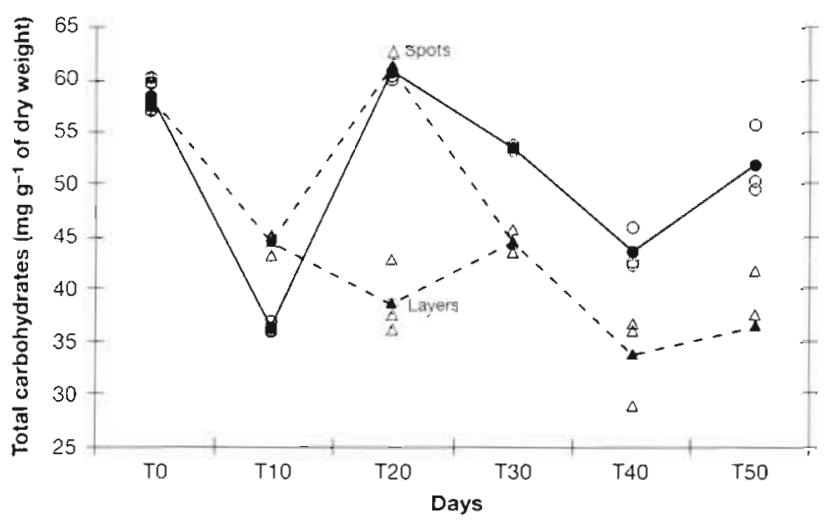

Fig. 6. Ruditapes philippinarum. Mean total carbohydrate amounts in control $(0)$ and infected $(\Delta)$ Japanese clams maintained under starvation conditions. Solid symbols: means

the control group were not significant (Mann-Whitney test, $p=0.417581$ ). No difference was noted between starved and fed clams in the control group $(\mathrm{p}=$ $0.101845)$ or in the infected group ( $\mathrm{p}=0.224838)$.

Water content. After refeeding, water content decreased (Fig. 9), lower values were found in the control group $(78 \%)$ but differences between control and infected clams were not significant $(p=0.128205)$. Inversely, differences were significant between starved and refed clams in the controls $(p<0.0025)$ and in infected clams $(p<0.025)$.

Total organic matter. Refeeding caused an increase in organic matter to $700 \mathrm{mg} \mathrm{g}^{-1}$ dry wt in control and infected clams (Fig. 10). At T40, control values were higher but no difference was found between the infected group and the control group ( $p=0.128205)$. On the other hand, differences between starved and refed clams were significant in the controls $(\mathrm{p}<$ $0.00025)$ and in the infected group $(p<0.025)$.

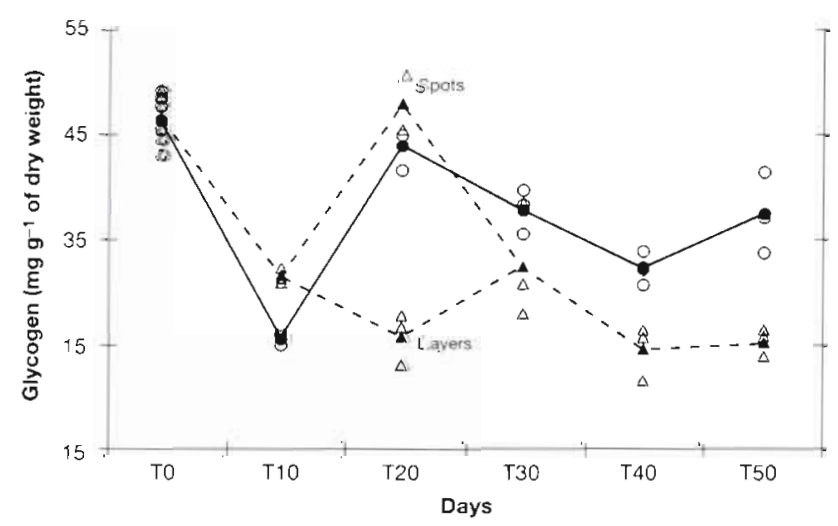

Fig. 7. Ruditapes philippinarum. Mean glycogen amounts in control $(0)$ and infected $(\Delta)$ Japanese clams maintained under starvation conditions. Solid symbols: means

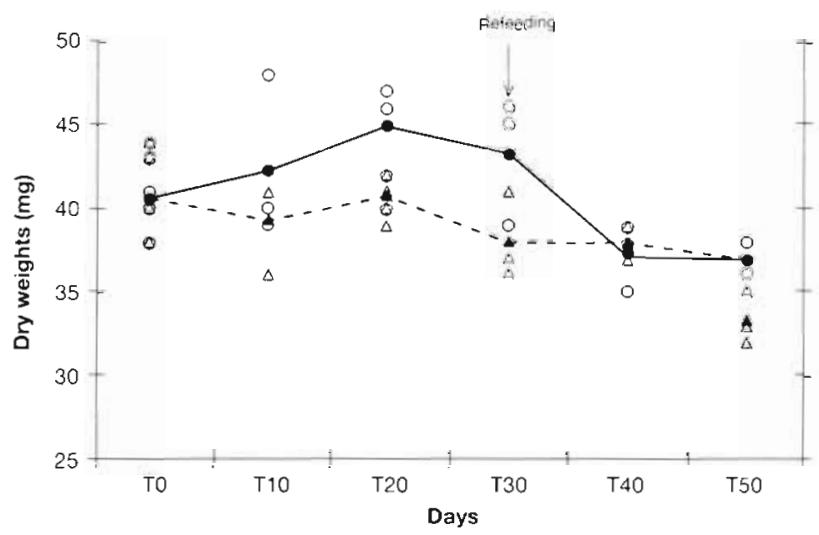

Fig. 8. Ruditapes philippinarum. Mean dry weights in control $(0)$ and infected $(\Delta)$ Japanese clams maintained under starvation conditions. After $30 \mathrm{~d}$, experimental clams were fed. Solid symbols: means

Proteins. As for total organic matter, protein amounts increased to $600-620 \mathrm{mg} \mathrm{g}^{-1}$ with refeeding (Fig. 11) and no difference was shown between control and infected groups $(p=0.689917)$. Inversely, higher values were significant in refed clams compared to starved clams in the control group $(p<0.01)$ and in infected group $(\mathrm{p}<0.05)$.

Total lipids. Refeeding involved an increase in total lipids amounts from 29 to $40 \mathrm{mg} \mathrm{g}^{-1}$ in the control group. The same pattern was observed later in infected clams (Fig. 12) but no difference was evident between the 2 groups $(p=0.0926954)$. Higher values in refed clams were significant only in the control group ( $<<0.01)$; this was not the case in the infected group ( $p=0.575171)$.

Neutral lipids. Amounts of neutral lipids showed the same pattern of distribution as total lipids with an increase from 16 to $25 \mathrm{mg} \mathrm{g}^{-1}$. As for total lipids, only the highest amounts measured in refed clams were significant in the control group $(p<0.005)$.

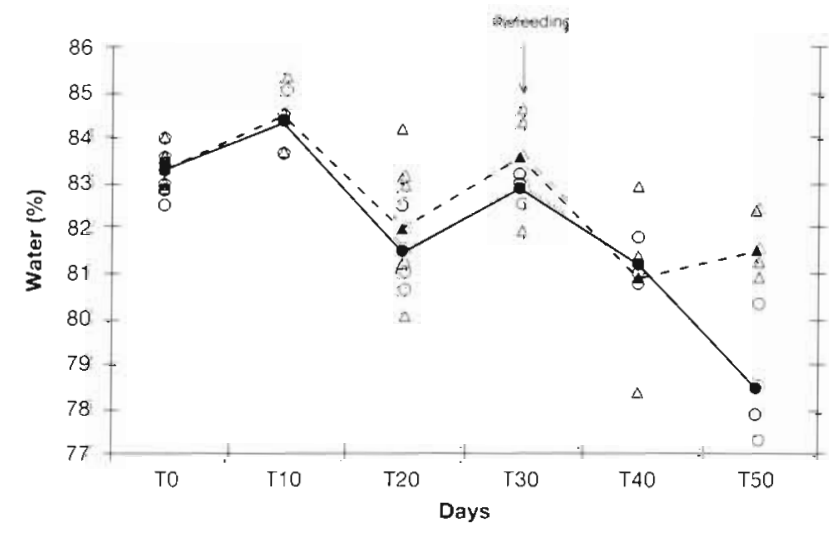

Fig. 9. Ruditapes philippinarum. Mean water content in control $(0)$ and infected $(\Delta)$ Japanese clams maintained under starvation conditions. After $30 \mathrm{~d}$, experimental clams were fed. Solid symbols: means 


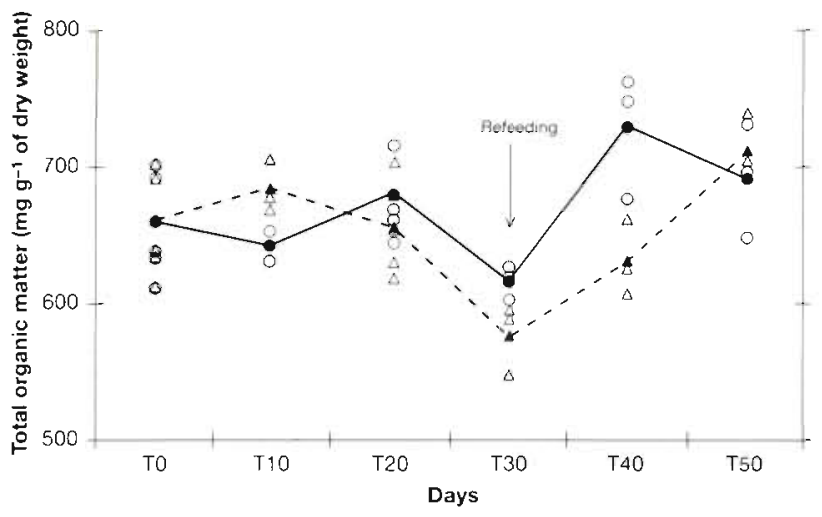

Fig. 10. Ruditapes philippinarum. Mean total organic matter amounts in control $(0)$ and infected $(\Delta)$ Japanese clams maintained under starvation conditions. After $30 \mathrm{~d}$, experimental clams were fed. Solid symbols: means

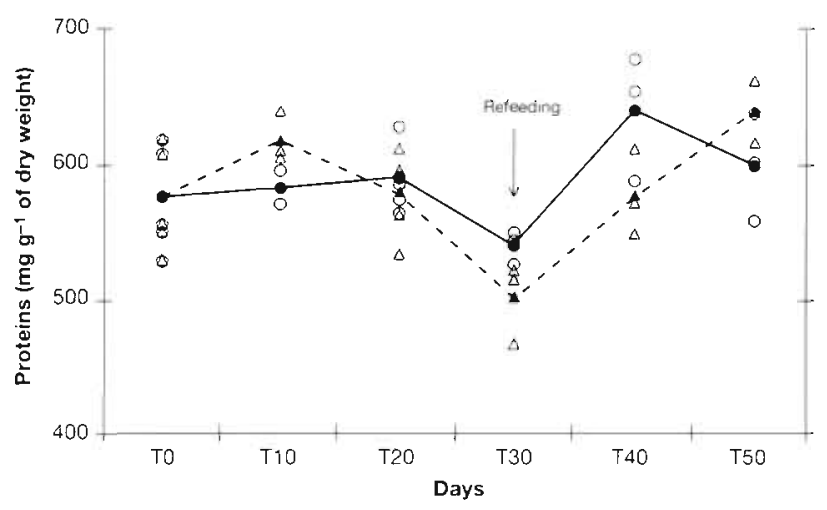

Fig. 11. Ruditapes philippinarum. Mean proten amounts in control $(0)$ and infected $(\Delta)$ Japanese clams maintained under starvation conditions. After $30 \mathrm{~d}$, experimental clams were fed. Solid symbols: means

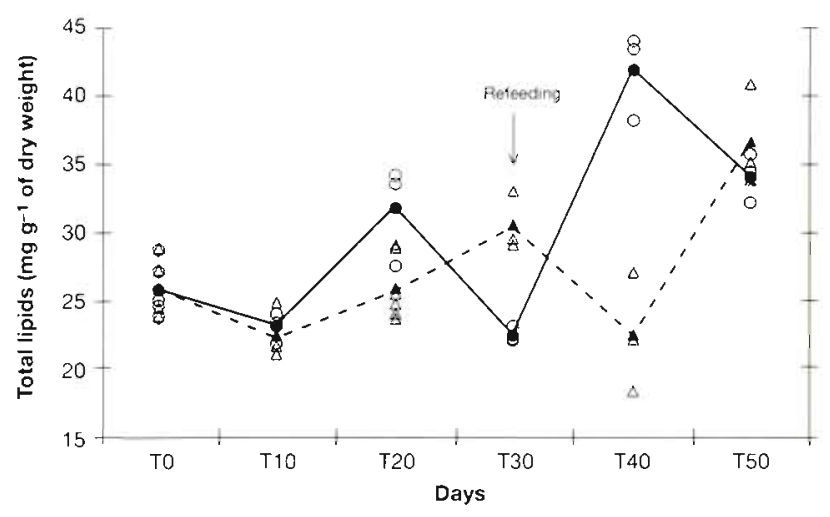

Fig. 12. Ruditapes philippinarum. Mean total lipid amounts in control $(O)$ and infected $(\Delta)$ Japanese clams maintained under starvation conditions. After $30 \mathrm{~d}$, experimental clams were fed. Solid symbols: means
Total carbohydrates. After $\mathrm{T} 40$, increases in total carbohydrate amounts occurred in the control group so final data were similar to start data $\left(60 \mathrm{mg} \mathrm{g}^{-1}\right.$ ). Inversely, in the infected group, total carbohydrates decreased to $30 \mathrm{mg} \mathrm{g}^{-1}$ (Fig 13) and a significant difference was obtained between the control and infected clams $(p<0.005)$. But, no difference was noted between starved and refed clams in the control group $(\mathrm{p}=0.173485)$ or in the infected group $(\mathrm{p}=$ $0.378476)$.

Glycogen. Final data were similar to start data in control clams $\left(50 \mathrm{mg} \mathrm{g}^{-1}\right)$. In the infected group, a decrease to $20 \mathrm{mg} \mathrm{g}^{-1}$ was obtained at T50 (Fig. 14) so the difference between the 2 groups (control and infected clams) was significant ( $p<0.005)$. As for total carbohydrates, no difference was found between starved and refed clams in controls $(p=0.471168)$ and infected individuals ( $\mathrm{p}=0.0655518)$.

\section{Influence of the pathological state}

If we consider the macroscopic signs, a similar pattern of changes in glycogen and total carbohydrate amounts is observed in starved (Fig. 15) and in refed clams (Fig 16). Healthy individuals (stage 0) showed the highest values, a decrease was measured in 'Stage 1' clams followed by a marked decrease in 'Stage 2 ' individuals $(\mathrm{p}<0.05)$ and no difference was noted between 'Stage 2 ' and 'Stage 3 ' individuals (total carbohydrates: $p=0,711528$; glycogen: $p=1$ ). Minimal values were found in recovered clams (Stage 4; Fig. 16) and their lower values were significant for total carbohydrates and glycogen amounts ( $p$ $<0.05$ ).

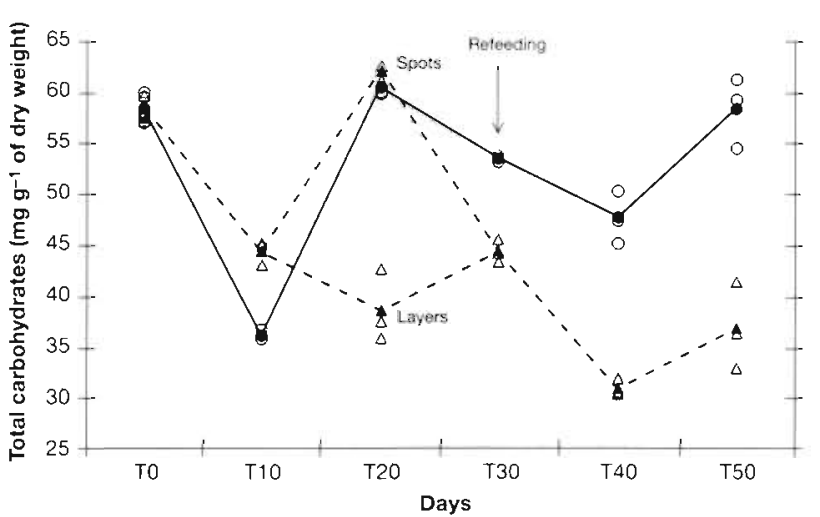

Fig. 13. Ruditapes philippinarum. Mean total carbohydrate amounts in control $(O)$ and infected $(\Delta)$ Japanese clams maintained under starvation conditions. After $30 \mathrm{~d}$, experimental clams were fed. Solid symbols: means 


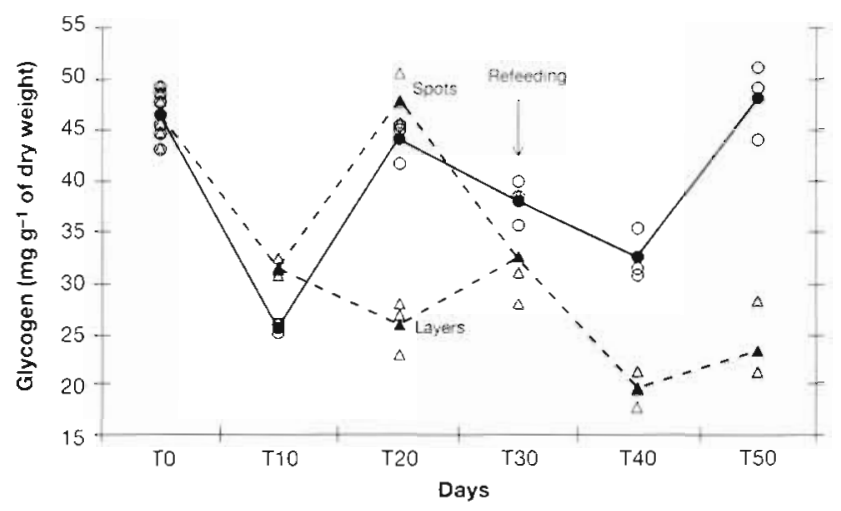

Fig. 14. Ruditapes philippinarum. Mean glycogen amounts in control $(0)$ and infected $(\Delta)$ Japanese clams, mantained under starvation conditions. After $30 \mathrm{~d}$, experimental clams were fed Solid symbols means

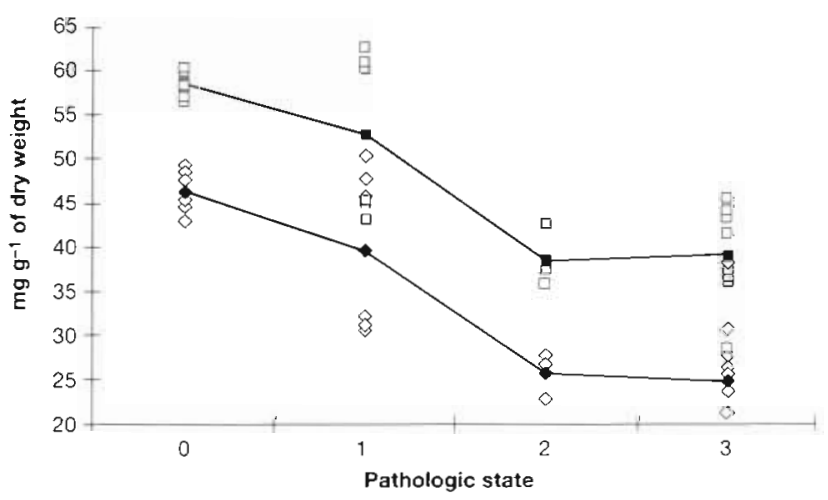

Fig. 15. Ruditapes philippinarum. Amounts of total carbohydrates ( $(\square)$ and glycogen ( 0 ) in starved Japanese clams in relation to pathological state. 0 : control clams; 1 . 'brown spots'; 2: 'brown layers'; 3: 'brown ring'. Solid symbols: means

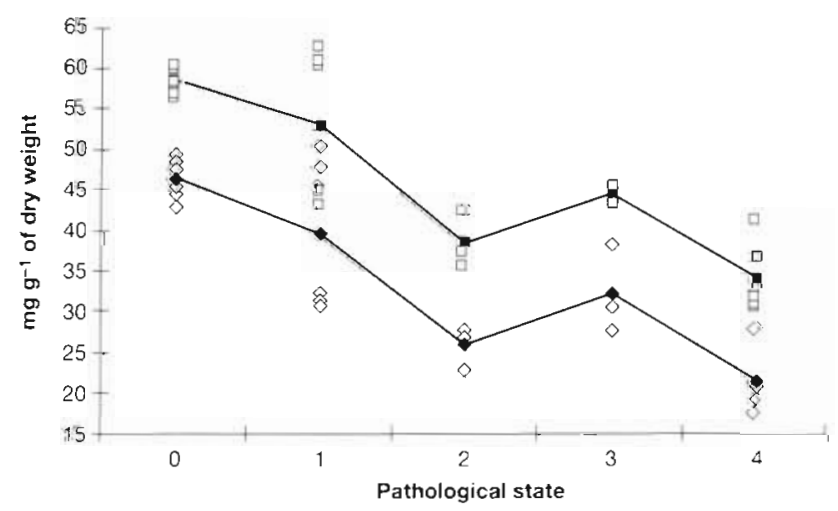

Fig. 16. Ruditapes philippinarum. Amounts of total carbohydrates (ㄷ) and glycogen $(0)$ in starved and refed Japanese clams in relation to pathological state. 0 : control clams; 1 'brown spots'; 2: 'brown layers'; 3: 'brown ring', 4: 'recovered' refed clams. Solid symbols: means

\section{DISCUSSION}

The digestive cycle of clams experimentally infected with Vibrio P1 exhibits alterations of the digestive diverticula and an increase in the level of tubule types representing the degenerative form; mass mortalities were also observed (Plana \& Le Pennec 1991, Plana 1995). Stress conditions induced a replacement of the 4 tubule types (Platt 1971) by an atrophic form (Moore et al. 1979, Lowe et al. 1981, Couch 1984). Environmental stress conditions induced a thinning of the digestive epithelium (Marigòmez et al. 1990). Bayne \& Thompson (1970) demonstrated that the digestive gland of Mytilus edulis exhibited marked seasonal variations in its biochemical composition suggesting a role in storage of metabolic energy reserves. Thompson \& Bayne (1972) observed a flow of ${ }^{14} \mathrm{C}$ labelled material from the digestive gland to the gonad and other tissues when $M$. edulis was fed Tetraselmis grown in medium containing $\mathrm{NaH}^{14} \mathrm{CO}_{3}$. Material from the digestive gland was also rapidly utilized during stress, as the recovery of a normal digestive cell structure and digestive gland index in fed mussels after an initial stress is considered essential to survival because all metabolic processes are ultimately dependent upon the functional integrity of the digestive gland (Thompson et al. 1974). However, morphological changes in the digestive gland may indicate stress effects which are not revealed by biochemical analysis (Bayne \& Thompson 1970). In the present study, measurements were performed to analyze the influence of 'brown ring' disease on the energy storage cycle in Ruditapes philippinarum.

The dry weights of tissues were stable in control clams during the experiment while a significant loss was observed in infected clams. Starvation did not appear to influence dry weight. Water content did not vary significantly between the groups but lower values were found in controls and refed clams. Riley (1976) showed that starvation involved dry weight losses and a general increase in the water content of the body of Crassostrea gigas. Barber et al. (1988) observed that mean dry weight of oysters was inversely correlated with severity of infection in oysters affected by a protozoan parasite, Haplosporidium nelsoni (MSX). In Ruditapes philippinarum, the dry weight was found to be lower when clams showed brown ring or had apparently recovered. This result suggests that clams may have diverted a substantial portion of their energy to fight the disease.

Organic matter declined in starved individuals and reached a maximum after refeeding in both control and infected clams. Proteins, the major biochemical component, had the same pattern of distribution as organic matter during the experiment, as did lipids, 
which are the lesser constituents. On the other hand, carbohydrate amounts declined in spite of refeeding in the infected group; this process was not observed in controls. According to various authors (e.g. Dare \& Edwards 1975, Pieters et al. 1979), protein levels follow a reverse pattern with respect to carbohydrates. The major physiological role of proteins is the supply of structural elements and the catalysis of metabolic reactions (Dittrich 1991), and numerous studies contested the importance of proteins as a reserve (Gabbott \& Bayne 1973, Zandee et al. 1980). The C/P ratio, an indication of the balance between carbohydrates and proteins in the tissues (Bayne \& Thompson 1970), showed the preferential utilization of carbohydrate reserves over proteins. Dry weight losses were found concomitantly with losses of carbohydrates in Ruditapes philippinarum. It is interesting to note that juveniles perform as adults in this respect. This is in agreement with the findings of Holland \& Hannant (1974) for Ostrea edulis, who showed that a change from neutral lipids (Holland \& Spencer 1973) to carbohydrates was the main energy reserve for larvae as well as for adults. Starvation and infection had no influence on lipid content. We can conclude that carbohydrates are the major energy source in young $R$. philippinarum.

The amounts of total carbohydrates varied significantly, which reflected the variations of glycogen. Zwaan \& Zandee (1972) and Gabbott \& Bayne (1973) showed that carbohydrate is stored as glycogen which reaches $90 \%$ of total carbohydrates in Tellina tenuis (Ansell \& Trevallion 1967, Trevallion 1971). In control clams, carbohydrate amounts were lowest in starved individuals and highest in the refed group. Conversely, lower amounts were found in refed infected clams than in starved infected clams in spite of their recovery. These results were disease related; decreases in amounts of total carbohydrates and glycogen were correlated with pathological state. Similarly, Barber et al. (1988) found that glycogen content was reduced in oysters in relation to MSX infection intensity.

During the early period of starvation, carbohydrates were the most catabolised reserve in terms of grams utilized in Crassostrea gigas (Riley 1976); glycogen is the major short-term energetic reserve but lipids are the most important substrate in terms of total energy. The contradiction between this energetic importance of lipids and their stability during the starvation could be resolved by Bressan \& Marin (1985) and Zandee et al. (1980); in adult bivalves, carbohydrate losses are a consequence of the conversion of carbohydrates into lipids during gametogenesis or in unfavourable conditions (e.g. after the decrease of phytoplankton biomass in winter). It is possible that carbohydrate and lipid contents were used by individuals but that we could measure only the decrease in carbohydrate amounts.
This hypothesis is confirmed by the small increase in lipid amounts in starved clams in control and infected groups and by the significant decrease in carbohydrate amounts.

Under normal circumstances, mortality in the population might follow depletion of proteins (Ansell \& Sivadas 1973). Epizootic mortalities were observed in tropical species of Donax, which did not appear to accumulate large lipid and carbohydrate reserves and did use protein content more rapidly during stress (Ansell et al. 1974). Goulletquer (1989) observed in Ruditapes philippinarum, during winter mortalities, a significant fall of glycogen that could be explained by a strong maintenance metabolism, twice as high than that of $R$. decussatus (Bodoy et al. 1986). It appears that $R$. philippinarum cannot adapt to environmental stressors so individuals rapidly use biochemical reserves when they are not in their 'functional area' (Bernard 1983); their filtration rates stay stable and cannot adapt to nutritional and seasonal variations (Deslous-Paoli et al. 1987). Some bivalves reduced respiration during starvation, hence they could limit energetic losses (Bayne \& Scullard 1977).

Refeeding after $30 \mathrm{~d}$ of starvation induced recovery of infected clams; the brown ring was masked by a new layer of calcium. However, carbohydrate amounts remained low whereas, as in Mytilus galloprovincialis (Bressan \& Marin 1985), the presence of food allowed the accumulation of both lipid and carbohydrate reserves in the control group. This abnormality could be explain by a high energetic requirement during the recovery, or by functional alterations, or both reasons Eble (1966) observed that the activity of digestive enzymes decreased with infection, indicating that oyster digestion was disrupted in oysters infected by parasites. Disease disrupted the normal energy storage cycle of the host by inhibiting feeding or digestion (Plana \& Le Pennec 1991, Plana 1995) or by utilizing stored nutrients (Thompson 1983). Refeeding permitted the storage and stability of lipid and protein content and calcification onto the valves by the rapid utilization of the carbohydrates to supply the metabolic demands.

Our study showed the importance of glycogen as an energy source, which maintained the integrity of individuals and permitted their recovery. After feeding, the food was ingested but carbohydrate reserves did not seem to accumulate in the infected group and mortalities occurred in starved as in refed infected clams. In general, when metabolic requirements increase, glycogen is the first component catabolised, especially in Ruditapes (Baghdiguian 1989). Individuals then become more sensitive to external factors and physiological variations (Hummel et al. 1986). Energetic requirements are enhanced by a direct utilisation of 
carbohydrates. The digestive diverticula store the neutral lipids and glycogen when food is digested (Henry 1987, Robinson et al. 1989) and redistribute them to the entire body. The histological alteration of the digestive gland in the infected clams would prevent this storage and this redistribution (Plana \& Le Pennec 1991, Plana 1995). Protein content may be used because of this degeneration under stress conditions (starvation, emersion, abnormal temperature); a decrease in protein amounts was observed in starved infected individuals. The same results were obtained in $R$. decussatus after a protracted starvation (Baghdiguian \& Riva 1984). Mortalities were significant in the starved group during all the experiments. In the refed group, it is possible that the recovery induced an 'energetic debt' whirh was not romnensated by the refeeding. In such a case, mortalities will be more likely since disease will not be resisted as in individuals in good condition. In the field, clams are subjected to various 'natural' stressors and this may contribute to mass mortalities.

Acknowledgements. The authors thank Dr M. N. Moore (Plymouth Marine Laboratory, Citadel Hild, Plymouth PL1 2PB, United Kingdom) and Dr Y.-M. Paulet (Laboratoire de Biologie Marine, Faculté des Sciences, Brest) for critically reviewing the manuscript.

\section{LITERATURE CITED}

Ansell AD, Sivadas P (1973) Some effects of temperature and starvation on the bivalve Donax vittatus (da Costa) in experimental laboratory populations. $J$ exp mar Biol Ecol 13:229-262

Ansell AD, Sivadas P, Narayanan B (1974) The ecology of two sandy beaches in South West India. IV. The biochemical composition of four common invertebrates. $J$ mar biol Ass India, p 103-108

Ansell AD, Trevallion A (1967) Studies on Tellina tenuis (Da Costa). I. Seasonal growth and biochemical cycle. J exp mar Biol Ecol 1:220-235

Baghdiguian S (1989) Influence de la température et des conditions trophiques sur la physiologie de Ruditapes decussatus L. (Mollusque lamellibranche). Proposition d'un nouveau domaine conceptuel de croissance. Thèse Dr EsSciences, Univ Marseille

Baghdiguian S, Riva A (1984) Etude des adaptations physiologiques entrainées par un jeûne prolongé chez Ruditapes decussatus, bivalve endogé. Haliothis 14:119-130

Barber BJ, Ford SE. Haskin HH (1988) Effects of the parasite MSX (Haplosporidium nelsoni) on oyster (Crassostrea varginica) energy metabolism. II. Tissue biochemical composition. Comp Biochem Physiol 91A(3):603-608

Bayne BL, Scullard C (1977) Rates of nitrogen excretion by species of Mytilus (Bivalvia: Mollusca). J mar biol Ass UK 57:355-369

Bayne BL, Thompson RJ (1970) Some physiological consequences of keeping Mytilus edulis in the laboratory. Helgoländer Meeresunters 20:526-552

Bernard FR (1983) Physiology and the mariculture of some northeastern Pacific bivalve molluscs. Can Spec Publ Fish Aquat Sci 63
Bodoy A, Riva A. Maitre Allain Th (1986) Comparaison de la respiration chez Ruditapes decussatus (L.) et Ruditapes philippinarum (Adams \& Reeve) en fonction de la température. Vie Milieu 36(3):83-89

Bressan M, Marin MG (1985) Seasonal variations in biochemical composition and condition index of cultured mussels (Mytilus galloprovincialis Lmk) in the lagoon of Venice (north Adriatic). Aquaculture 48:13-21

Couch J (1984) Atrophy of diverticular epithelium as an indicator of environmental irrritants in the oyster Crassostrea virginica. Mar environ Res 14:525-526

Dare PJ, Edwards DB (1975) Seasonal changes in flesh weight and biochemical composition of mussels (Mytilus edulis L.) in the Conwy estuary, north Wales. J exp mar Biol Ecol 18:89-97

Deslous-Paoli JM, Héral M, Goulletquer P, Boromthanarat W, Razet D, Garnier J, Prou J, Barillet L (1987) Evolution saisonnière de la filtration de bivalves intertidaux dans des conditions naturelles. Journées du GABIM, L'Houmeau, iNov 860 Océanis $13(4-5 j: 575-579$

Dittrich B (1991) Biochemical composition of the parasitic amphipod Hyperia galba in relation to age and starvation. J comp Physiol B 161:441-449

Dubois $M$, Gillies KA, Hamilton JK, Reebers PA, Smith F (1956) Colorimetric method for the determination of sugars and related substances. Analyt Chem 28:350-356

Eble AF (1966) Some observations on the seasonal distribution of selected enzymes in the American oyster as revealed by enzyme histochemistry. Proc Natn Shellfish Ass 56:37-42

Flassch JP (1987) L'élevage des palourdes en France en 1987. Aqua Rev 15:12-16

Gabbott PA, Bayne BL (1973) Biochemical effects of temperature and nutritive stress on Mytilus edulis L. J mar biol Ass UK 53:269-286

Goulletquer P (1988) Anomalies de calcification chez la palourde japonaise Ruditapes philippinarum: caractérisation et comparaison des compositions en acides aminés de différentes parties de la coquille analysées par HPLC. Aquaculture 22:45-48

Goulletquer P (1989) Mortalité hivernale chez la palourde japonaise Ruditapes philippinarum sur le Littoral Atlantique: aspects biochimique et écophysiologique. Haliotis 19:215-226

Goulletquer P, Nedhif $M$. Héral $M$ (1986) Perspectives de développement de l'élevage de la palourde japonaise Ruditapes philippinarum dans le bassin ostréicole de Marennes-Oléron. Note Comm Meet int Coun Explor Sea CM-ICES 1986/F:42

Henry M (1987) La glande digestive de la palourde méditerranéenne Ruditapes decussatus L.: recherches ultrastructurales, cytochimiques, écophysiologiques et écotoxicologiques. Thèse Dr Es-Sciences, Océanologie, I, II, Univ Aix-Marseille III

Holland DL, Gabbott PA (1971) A micro-analytical scheme for the determination of protein, carbohydrate, lipid and RNA levels in marine invertebrate larvae. J mar biol Ass UK 51:659-668

Holland DL. Hannant PJ (1973) Addendum to a microanalytical scheme for the biochemical analysis of marine invertebrate larvae. J mar biol Ass UK 53:833-838

Holland DL, Hannant PJ (1974) Biochemical changes during growth of the spat of the oyster Ostrea edulis L. J mar biol Ass UK 54:1007-1.016

Holland DL, Spencer BE (1973) Biochemical changes in fed and starved oysters, Ostrea edulis L. during larval development, metamorphosis and early spat growth. J mar biol Ass UK 53:287-298 
Hummel H, Meijboom A, De Wolf L (1986) The effects of extended periods of drainage and submersion on condition and mortality of benthic animals. J exp mar Biol Ecol $103: 251-266$

Lowe DM, Moore MN, Clarke KR (1981) Effects of oil on digestive cells in mussels: quantitative alterations in cellular and lysosomal structure. Aquat Toxicol 1:213-226

Lowry OM, Rosebrough NJ, Farr AL, Randall RJ (1951) Protoin measurement with the Folin phenol reagent $J$ biol Chem 193:265. 275

Marigomez JA, Saez V, Cajaravilie MP, Angulo E (1990) A planimetric study of the mean epithelial thickness (MET) of the molluscan digestive gland over the tidal cycle and under environmental stress conditions. Helgoländer Meeresunters 44:81-94

Marsh JB, Weinstein DB (1966) Simple charring method for determination of lipids. J Lipids Res 7:574-576

Moore MN, Lowe DM, Moore SL (1979) Induction of lysosomal destabilisation in marine bivalve molluscs exposed to air. Mar Biol Lett 1:47-57

Paillard C, Maes P (1990) Etiologie de la maladie de l'anneau brun' chez Tapes philippinarum: pathogénicité d'un Vibrio sp. Cr Acad Sci Paris 310 (Sér III):15-20

Paillard C, Percelay L, Le Pennec M, Picard D (1989) Origine pathogène de l'anneau brun' chez Tapes philippinarum (Mollusque, Bivalve). Cr Acad Sci Paris 309 (Sér IrI):235-241

Pieters H, Kluytmans JH, Zurbug W, Zandee DI (1979) The influence of seasonal changes on energy metabolism in Mytilus edulis (L.). 1. Growth rate and biochemical composition in relation to environmental parameters and spawning. In: Naylor E, Hartnoll RG (eds) Cyclic phenomena in marine plants and animals. Pergamon Press, Oxford, p 285-292

Plana S (1995) Perturbations de la glande digestive et du métabolisme chez la palourde aquacole, Ruditapes phlippinarum, affectée par la maladie de l'anneau brun. PhD thesis, Univ Brest, I, Il

Responsible Subject Editor: A.K. Sparks, Seattle, Washington, USA
Plana S, Le Pennec M (1991) Alterations in the digestive diverticula and nutritional consequences in the clam Rudrtapes philippinarum infected by a Vibrio. Aquat Living Resour 4:255-264

Platt AM (1971) Studies on the digestive diverticula of Mytilus edulis L. PhD thesis, Queen's University, Belfast

Riley RT (1976) Changes in the total protein, lipid, carbohydrate, and extracellular body-fluid free amino acids of the Pacific oyster, Crassostrea grgas, during starvation. Proc Natl Shellfish Ass 57:89-90

Robinson WE, Langton RW, Boggs CC (1989) Chlorophyllous pigment and lipid stores in the digestive gland of inshore and offshore populations of the deep-sea scallop Placopecten magellanicus. Mar Ecol Prog Ser 52:181-191

Sokal RR, Rohlf FJ (1985) Biometry, 2nd edn. WH Freeman, San Francisco

Thompson RJ (1983) The relationship between food ration and reproductive effort in the green sea urchin, Strongylocentrotus droebachiensis. Oecologia 56:50-57

Thompson RJ, Bayne BL (1972) Active metabolism associated with feeding in the mussel Mytilus edulis L. J exp mar Biol Ecol 9:111-124

Thompson RJ, Ratcliffe NA, Bayne BL (1974) Effects of starvation on structure and function in the digestive gland of the mussel (Mytilus edulis L.). J mar biol Ass UK 54 $699-712$

Trevallion A (1971) Studies on Tellina tenuis da Costa. III Aspects of general biology and energy flow. J exp mar Biol Ecol 7:95-122

Zandee DI, Kluitmans JH, Zurburg W, Pieters H (1980) Sea sonal variations in biochemical composition of Mytilus edulis with reference to energy metabolism and gametogenesis. Neth J Sea Res 14:1-29

Zwaan A de, Zandee DI (1972) Body distribution and seasonal changes in the glycogen content of the common sea mussel Mytilus edulis. Comp Biochem Physiol 43A: $53 \cdot 58$

Manuscript first received: July 6, 1993

Revised version accepted: September 21, 1995 